\title{
PENGARUH PEMBERIAN MINYAK BIJI JINTEN HITAM (Nigella sativa) TERHADAP INTERLEUKIN-21 (IL-21) PADA PASIEN BERESIKO SINDROM METABOLIK
}

\section{THE INFLUENCE OF BLACK CUMIN OIL (Nigella sativa) TO INTERLEUKIN-21 (IL-21) IN PATIENTS WITH RISK OF METABOLIC SYNDROME}

\author{
Luky Septiansyah Anjastika' ${ }^{1}$ Akrom $^{2}$ \\ ${ }^{1}$ Prodi Farmasi, Sekolah Tinggi Farmasi YPIB Cirebon \\ Jl. Perjuangan, Majasem, Kota Cirebon \\ ${ }^{2}$ Fakultas Farmasi, Universitas Ahmad Dahlan Yogyakarta \\ Jl. Prof. Dr. Soepomo, Janturan, Yogyakarta
}

Summited : 17 Februari 2020Reviewed : 27Maret 2020Accepted : 29Maret 2020

\begin{abstract}
ABSTRAK
Stress oksidatif merupakan salah satu penyebab sindroma metabolik yang akan memicu pembentukan sitokin proinflamasi Interleukin-21 (IL-21). Minyak biji jintan hitam (MBJH)memilki efek sebagai antioksidan dan antiinflamasi.Tujuan dari penelitian ini yaitu mengetahui pengaruh pemberian $\mathrm{MBJH}$ terhadap IL-21 terhadap pasien berisiko sindrom metabolik (SM) selama 21 hari.Metode penelitian menggunakan posttest only control group designdengan dosis bertingkat.Jumlah subjek penelitian sebanyak 99 pasien resiko sindrom metabolik yang memenuhi kriteria inklusi dibagi ke dalam tiga kelompok.Tiap kelompok terdiri dari 33 pasien sindrom metabolik. Pada kelompok 1 pasien mendapatkan MBJH dengan dosis $1,5 \mathrm{ml} /$ hari selama 21 hari dan pada kelompok 2 pasien mendapatkan MBJH dengan dosis dan $3 \mathrm{ml} /$ hariselama 21 hari. Kelompok 3 diberi placebo selama 21 hari.Pengujian aktivitas dari IL-21 tiap kelompok dilakukan pada hari ke-21 Kemudian dilakukan analisis data presentase rata-rata aktivitas dari IL-21 untuk kelompok perlakuan dan kontrol. Data persentase antar kelompok perlakuan dibandingkan secara statistik dengan taraf kepercayaan $95 \%$. Hasil penilitian menunjukan bahwa nilai rerata \pm SD interleukin-21 pada pemberian $\mathrm{MBJH}$ dosis $1,5 \mathrm{ml} /$ hari yaitu $2.229 \pm 1.7629$, dosis $3 \mathrm{ml} / \mathrm{hari}$ yaitu 3.665 \pm 6.0600 , dan placebo selama 21 hari yaitu $2.145 \pm 1.4199$ dengan nilai $p>0,05$. Sehingga dapat disimpulkan bahwa ekspresi IL-21 pada pasien berisiko sindrom metabolik yang mendapatkan MBJH dosis $3 \mathrm{ml} /$ hari lebih tinggi dibandingkan yang mendapat dosis 1,5 $\mathrm{ml} /$ hari selama 21 hari.
\end{abstract}

Kata Kunci : Minyak Biji Jinten Hitam (Nigella sativa), sindrom metabolik, stress oksidatif, IL-21.

\begin{abstract}
Oxidative stress is one of the causes of metabolic syndrome which will trigger the formation of proinflammatory cytokines Interleukin-21 (IL-21). Black cumin oil (MBJH) has antioxidant and anti-inflammatory effects. The purpose of this study was to determine the effect of giving MBJH to IL-21 for patients at risk of developing metabolic syndrome (SM) for 21 days. The research method uses the posttest only control group design with multiple doses. The number of research subjects was 99 patients with metabolic syndrome risk who met the inclusion criteria divided into three groups. Each group consisted of 33 metabolic
\end{abstract}


syndrome patients. Group 1 patient received MBJH at a dose of $1.5 \mathrm{ml} /$ day for 21 days and in group 2 patients received $\mathrm{MBJH}$ at a dose and $3 \mathrm{ml} /$ day for 21 days. Group 3 was given a placebo for 21 days. Testing the activity of IL-21 for each group were carried out on the 21st day. Then an analysis of data on the average percentage of activity from IL-21 was conducted for the treatment and control groups. Percentage data between treatment groups were compared statistically with a confidence level of $95 \%$. The results of the study showed that the mean value $\pm \mathrm{SD}$ interleukin-21 at the MBJH dose $1.5 \mathrm{ml} /$ day was $2,229 \pm 1.7629$, the dose of $3 \mathrm{ml} /$ day was $3,665 \pm 6,0600$, and the placebo for 21 days was $2,145 \pm 1.4199$ with a value of $p>0$.5. So it can be concluded that the expression of IL-21 in patients at risk of metabolic syndrome who get MBJH dose $3 \mathrm{ml} /$ day is higher than those who get a dose of $1.5 \mathrm{ml} /$ day for 21 days.

Keywords : Black Cumin Seed Oil (Nigella sativa), metabolic syndrome, oxidative stress, IL-21.

\section{Penulis Korespondensi : \\ Luky Septiansyah Anjastika \\ Sekolah Tinggi Farmasi YPIB Cirebon \\ Email :lukyseptian@gmail.com / Hp 081324009027}

\section{PENDAHULUAN}

Pembangunan bidang kesehatan pada dasarnya ditujukan untuk meningkatkan kesadaran, kemauan dan kemampuan hidup sehat bagi setiap orang untuk mewujudkan derajat kesehatan yang optimal. (Kemenkes RI, 2010). Pembangunan kesehatan yang di arahkan kepada peningkatan kemampuan masyarakat untuk hidup sehat dan dapat menolong dirinya sendiri, serta mampu untuk mengatasi permasalahan kesehatan yang dihadapi dari lingkungan dan perilaku yang tidak mendukung untuk hidup sehat.

Sindrom metabolik merupakan sindrom yang menyebabkan meningkatnya terjadinya faktor yang berhubungan dengan meningkatkan resiko penyakit kardiovaskuler, yaitu diabetes mellitus (DM) atau peningkatan glukosa darah puasa, obesitas sentral, dyslipidemia dan hipertensi (Alberti et al;2006). Di Indonesia sendiri tingkat prevalensi SM menurut data dari riset kesehatan dasar (Riskesdas) pada tahun 2007 dan 2013 mengalami peningkatan. dimana, prevalensi penduduk Indonesia yang mengalami hipertensi sebesar 7,6\%, diabetes mellitus sebesar $1,1 \%$, obesitas sentral sebesar $18,8 \%$ dan jantung sebesar $0,9 \%$ (Kemenkes RI,2007). Sedangkan pada tahun 2013 prevalensi penduduk Indonesia yang mengalami hipertensi sebesar $9,5 \%$, diabetes mellitus sebesar 2,1\%, obesitas sentral sebesar 26,6\% dan jantung sebesar $1,5 \%$ (Kemenkes RI, 2013). Salah satu penyebab dari sindroma metabolik ini adalah stresoksidatif yang akhir-akhir ini mudah sekali terjadi akibat faktor lingkungan dan gaya hidup yang tidak sehat.

Stres oksidatif terjadi karena adanya ketidakseimbangan antara prooksidan dan antioksidan dalam sel. Kondisi kelebihan berat badan, dislipidemia, hiperglikemi dan hipertensi memicu reaksi peroksidasi, glikasi dan terjadinya jejas seluler yang akan menghasilkan radikal bebas dan senyawa prooksidan. Adanya ledakan oksidatif pada mitokhondria akibat meningkatnya aktivitas makrofag menghasilkan reactive oxygen species (ROS) dan reactive nitrogen species (RNS) yang akan semakin memberatkan stres oksidatif dan reaksi inflamasi yang ditimbulkannya (Bajak, 2005).

Adanya stres oksidatif diikuti dengan peningkatan jumlah ROS yang berlebih yang dapat menekan proliferasi limfosit sehingga jumlah serta aktivitas sel T CD4 dan sel T CD4CD25 menurun (Van de veen, 2001). Limfosit Thelper (CD4+), limfosit T sitolitik (Cytolitic T Lymphocite/CTL/CD8), interleukin-12 (IL-12) dan interferon gama (IFN y) merupakan komponen sistem imun yang berperan penting dalam penyelenggaraan imunosurveilans dan respon imun seluler kanker (Vecchio et al., 2007; Ribas et al., 2007; Wald et al., 2006). 
Fungsi dari IL-21 adalah menstimulasi sel B agar berdiferensiasi menghasilkan antibodi sebagai akibat terjadinya inflamasi pada jaringan.Stimulasi ini terjadi bila IL-21 berikatan dengan IL-21 reseptor pada sel B, juga berperan dalam proliferasi dan pematangan sel natural killer (NK) populasi dari sumsum tulang. (Edi et al., 2012) IL-21 juga merupakan sitokin proinflamasi yang meningkat akibat adanya stress oksidatif. pada pasien yang mengalami penyakit inflamasi seperti rheumatoid arthritis, multiple sclerosis, inflammatory bowel diseases juga terlihat terjadi peningkatan ekspresi IL-21. Sitokin IL-21 memberikan efek biologis dalam beberapa jenis penyakit hematologi, seperti trombositopenia imun (ITP), limfositik kronis leukemia (CLL), multiple myeloma (MM) dan limfoma (Niu et al., 2013). IL-21 juga menstimulasi sel B berdiferensiasi menghasilkan antibodi (Edi et al., 2012).

Minyak biji jinten hitam banyak mengandung asam lemak tak jenuh yaitu asam linoleat dan linolenat serta minyak atsiri dengan zat aktif timokuinon, negelin dan nigelon (Akrom, 2013; Farrah et al., 2004; Nickavar et al., 2003). Asam lemak tak jenuh maupun timokuinon merupakan antioksidan kuat dan imunomodulator (Akrom, 2013; Iddamaldeniya, 2006; El Sayed \&Fukushima, 2003; Mousa et al., 2004; Randhawa et al., 2002) Berdasarkan uraian tersebut perlu dilakukan penelitian berupa Pengaruh Pemberian Minyak Biji Jinten Hitam (Nigella Sativa) Terhadap Interleukin-21 (IL-21) Pada Pasien Beresiko Sindrom Metabolik.

Tujuan dari penelitian ini adalah mengetahui pengaruh pemberian MBJH selama 21 hari terhadap ekspresi IL-21 pada pasien beresiko sindrom metabolik yang diberi MBJH.

\section{METODE PENELITIAN}

\section{Alat dan Bahan Uji}

Instrumen penelitian yang digunakan pada penelitian ini adalah alat flowsitometer (FACS Calibur 80) untuk melihat aktifitas ekspresi IL-21.Bahan uji yang digunakan pada penelitian ini yaitu kapsul imunax@ yang berisi minyak biji jinten hitam (MBJH) yang telah terstandarisasi dengan kadar timokuinon $2,72 \%$ dan asam lemak berupa kaprilat $0,15 \%$, kaprat $0,1 \%$, laurat $0,18 \%$, miristat $12,27 \%$, palmitat $0,28 \%$, stearat $7,99 \%$, oleat $0,07 \%$, linoleat $2,85 \%$, eikosanoat $3,15 \%$, eikosenat $0,25 \%$, eikosadienoat $0,03 \%$, arakhidonat $0,03 \%$, eikopentanoat $0,03 \%$, behenat $0,06 \%$, dokoheksanoat $0,04 \%$, terakosanoat $0,02 \%$ serta placebo berupa kapsul kosong.

\section{Jenis dan Rancangan penelitian}

Penelitian ini menggunakan desain penelitian eksperimental posttest only control group design dengan dosis bertingkat.Total subjek pada penelitian ini berjumlah 99 orang yang mengalami resiko sindrom metabolik dibagi kedalam 3 kelompok, tiap kelompok berjumlah 33 orang. Pada kelompok 1 pasien mendapatkan minyak biji jinten hitam dengan dosis $1,5 \mathrm{ml} /$ hari selama 21 hari dan pada kelompok 2 pasien mendapatkan minyak biji jinten hitam dengan dosis dan $3 \mathrm{ml} /$ hari selama 21 hari. Kelompok 3 diberi placebo (cangkang kosong) selama 21 hari.Pengujian aktivitas dari IL-21 tiap kelompok dilakukan pada hari ke-21 kemudian dilakukan analisis data presentase rata-rata aktivitas dari IL-21.

\section{Prosedur penelitian}

\section{Langkah I penelitian penentuan subjek penelitian}

Penentuan calon subjek penelitan berdasarkan pengkajian data rekam medik pasien di Puskesmas Jetis 1 Bantul yang mengalami resiko sindrom metabolik meliputi penyakit hipertensi atau dislipidemia atau diabetes mellitus. Setelah mendapatkan data dari rekam medik, maka calon subjek tersebut diminta untuk berpartisipasi dalam penelitian dengan mengisi persetujuan informed consent. Kemudian sebanyak 99 pasien sindrom metabolik yang telah memenuhi persyaratan penelitian, menyatakan kesediaannya sebagai subjek penelitian dan telah mengisi persetujuan informed consent tersebut dibagi kedalam 3 
kelompok secara acak dan homogen. Pasien yang mengalami resiko SM diminta untuk mengisi case report form selama berjalannya penelitian ini.

2. Langkah II penelitian perlakuan subjek penelitian

Pasien beresiko SM diberikan kapsul MBJH selama 21 hari.Pada kelompok 1 pasien mendapatkan minyak biji jinten hitam dengan dosis $1,5 \mathrm{ml} / \mathrm{hari}$ selama 21 hari dan pada kelompok 2 pasien mendapatkan minyak biji jinten hitam dengan dosis dan $3 \mathrm{ml} / \mathrm{hari}$ selama 21 hari. Kelompok 3 diberi placebo (cangkang kosong) selama 21 hari.Pada minggu ke-3 dilakukan pemeriksaan aktivitas ekspresi IL-21.

\section{Langkah III penelitian pemeriksaan ekspresi IL-21}

Darah tepi diambil dari vena cubiti oleh tenaga analis yang sudah terlatih dengan prosedur sebagai mana tertera dalam protokol yang telah direview komite etik penelitian Universitas Ahmad Dahlan.Dari darah yang sudah terkumpul kemudian dilakukan pemeriksaan ekspresi IL-21 dengan menggunakan flowcytometri.Darah yang telah ditampung dalam tabung vacutainer yang berisi antikoagulan, siap diperiksa dengan flowcitometer dengan prosedur sebagai berikut: (i). Spesimen dipipet ke dalam tabung falcon sebanyak $50 \mu \mathrm{L}$.(ii). Menambahkan $5 \mu \mathrm{L}$ reagen FITC anti-human IL-21. (iii). Campur homogen pada vortex mixer, kemudian diinkubasi 15 menit $20-25^{\circ} \mathrm{C}$ pada ruang gelap. (iv). Mengencerkan $50 \mu \mathrm{L}$ larutan pelisis I O x FACS dengan akuades sebanyak 450 $\mu \mathrm{L}$ kemudian campur homogen. (v). Setelah waktu inkubasi selesai, sampel ditambah 450 $\mu \mathrm{L}$ reagen FACS (1x) yang sudah diencerkan. (vi). Campur homogen, kemudian inkubasi 15 menit $20-25^{\circ} \mathrm{C}$ pada ruang gelap. (vii). Setelah masa inkubasi selesai, dilakukan analisis menggunakan alat FACS flowcitometer.

\section{Analisis Data}

Dari hasil penelitian dianalisis statistik dengan metode eksperimen.Data diolah secara statistik menggunakan instrument software SPSS untuk mengetahui pengaruh pemberian minyak biji jinten hitam (Nigella sativa) terhadap IL-21 pada pasien beresiko sindrom metabolik.

\section{HASIL DAN PEMBAHASAN}

Desain penelitian ini menggunakan metode desain penelitian eksperimentalposttest only control group design dengan dosis bertingkat. Total subjek pada penelitian ini berjumlah 99 orang yang mengalami resiko sindrom metabolik yang kemudian dibagi dalam 3 kelompok, tiap kelompok berjumlah 33 orang. Pada kelompok 1 pasien mendapatkan minyak biji jinten hitam dengan dosis $1,5 \mathrm{ml} / \mathrm{hari}$ (1x3 kapsul lunak MBJH/hari) 1 kapsul berisi $0,5 \mathrm{ml}$ MBJH diminum pada pagi hari 30 menit sesudah makan selama 21 hari. Pada kelompok 2 pasien mendapatkan minyak biji jinten hitam dengan dosis $3 \mathrm{ml} / \mathrm{hari}(2 \times 3$ kapsul lunak MBJH/hari) diminum pada pagi dan malam hari 30 menit sesudah makan selama 21 hari. Kelompok 3 diberi placebo (cangkang kosong) selama 21 hari.Pengujian aktivitas dari IL-21 tiap kelompok dilakukan pada hari ke-21 kemudian dilakukan analisis data presentase rata-rata aktivitas dari IL-21 untuk kelompok perlakuan dan kontrol.

\section{Data Subjek Penelitian}

Subjek penelitian yang sesuai kriteria inklusi sebanyak 120 pasien dan yang bersedia untuk mengikuti penelitian dengan menyetujui inform concern sebanyak 112 pasien. 
Berdasarkan Flowchart(gambar 1), dapat dilihat bahwa pada kelompok 1 total subjek yang menyelesaikan prosedur intervensi MBJH 1,5ml/hari adalah sebanyak 31 subjek (94\%). Untuk sisanya sebanyak 2 subjek (6\%) tidak dapat menyelesaikan penelitian karena keduanya mengalami efek samping yang berupa: satu subjek (3\%) mengalami peningkatan tekanan darah dan satu subjek lainnya (3\%) mengalami mual-muntah. Pada kelompok 2 total subjek yang menyelesaikan prosedur intervensi $\mathrm{MBJH} 3 \mathrm{ml} /$ hari adalah sebanyak 31 subjek (94\%). Untuk sisanya sebanyak 2 subjek (6\%) tidak dapat menyelesaikan penelitian karena keduanya mengalami efek samping yang berupa: satu subjek (3\%) mengalami gastritis dan satu subjek lainnya (3\%) menjalani prosedur operasi batu ginjal.

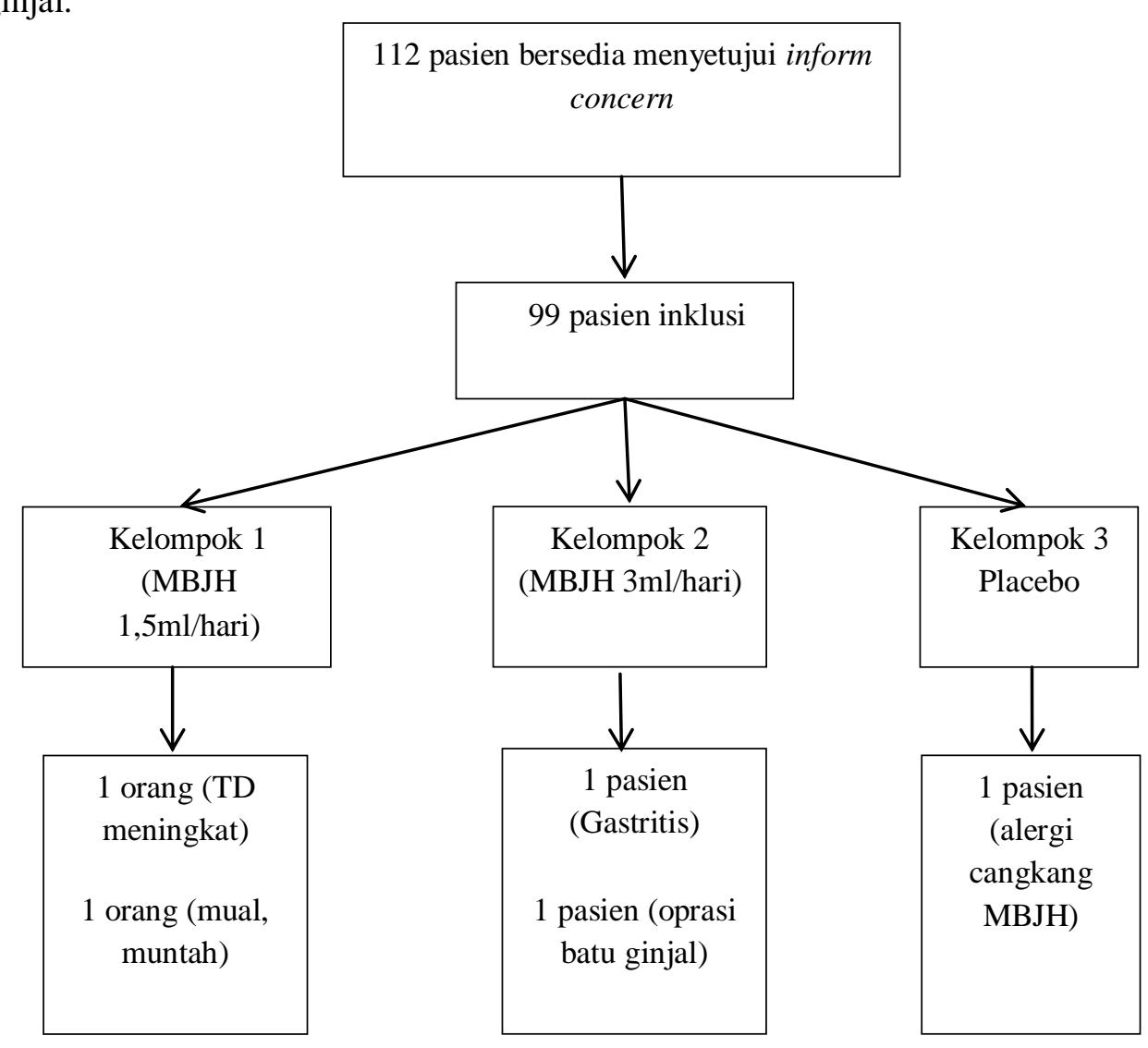

Gambar 1. Flow chart subjek penelitian

\section{Hasil Pengukuran Ekspresi Interleukin-21 Pada Pasien Beresiko Sindrom Metabolik yang diberi Minyak Biji Jinten Hitam (MBJH).}

Data hasil pengukuran ekspresi IL-21 yang dianalisis menggunakan Anova pada 3 kelompok pasien subjek penelitian beresiko sindrom metabolik yang diberi MBJH masingmasing sebanyak 1,5ml/hari dan 3ml/hari ditunjukan pada tabel 1 . 
Tabel I.Nilai rata-rata ekspresi Interleukin-21 pada uji Anova

\begin{tabular}{ll}
\hline \multicolumn{1}{c}{ Kelompok } & \multicolumn{1}{c}{ Rerata \pm SD } \\
\cline { 2 - 2 } & \multicolumn{1}{c}{ Hitung jenis IL-21 } \\
\hline MBJH dosis 1,5 ml/hari selama 21 hari & $2.229 \pm 1.7629$ \\
\hline MBJH dosis 3 ml/hari selama 21 hari & $3.665 \pm 6.0600$ \\
\hline Placebo selama 21 hari & $2.145 \pm 1.4199$ \\
\hline & $\mathrm{P}=0,214$ \\
\hline
\end{tabular}

Dari tabel I diketahui bahwa nilai rerata \pm SD interleukin-21 pada pemberian MBJH dosis $1,5 \mathrm{ml} /$ hari yaitu $2.229 \pm 1.7629$, dosis $3 \mathrm{ml} /$ hari yaitu $3.665 \pm 6.0600$, dan placebo selama 21 hari yaitu $2.145 \pm 1.4199$ dengan nilai $p>0,05(\mathrm{p}=0,214)$. Hal ini tidak sejalan dengan penelitian sebelumnya dimana pemberian Nigella sativa L. dapat menyebabkan demodulator pada sitokin proinflamasi yang dihasilkan oleh Thelper 1 dan sitokin. Zat aktif yang terdapat pada minyak biji jinten hitam dapat membangkitkan sistem imun dengan kemampuanya menaikan sel Thelper, sel Tsupressor, dan sel NK yang merupakan produk sel lifosit (islam, 2016; Gilani et al., 2004).

Dalam minyak biji jintan hitam terdapat kandungan minyak atsiri thymoquinone yang memiliki mekanisme kerja dengan menghambat peroksidasi lipid non-enzimatik pada liposom dan memiliki potensi dalam menetralkan radikal bebas serta menghambat sitokin proinflamasi seperti interleukin-1 $\beta$, Interleukin-8 dan kemokin seperti machropage chemotactic protein (MCP)-1 dengan mekanisme kerja melalui penghambatan terhadap TNF- $\alpha$ yang menginduksi aktivasi faktor transkripsi nuclear factor kappa B (NF-kB) yang terlibat dalam jalur signaling IL-21 serta menghambat translokasi NF-kB ke dalam Nucleus (Ricky, 2011). Pemberian MBJH pada sindroma metabolik akan menghambat aktivasi IL-21 melalui penurunan deferensiasi dari T-helper yang juga memproduksi reseptor IL-21 (IL21R) serta penghambatan pada jalur signaling STAT3.Tetapi hasil penelitian ini juga dipengaruhi pula oleh kondisi fisiologis tubuh dan pola hidup seperti merokok, kurang berolah raga, dan penggunaan obat-obatan sebagai pengobatan jangka panjang dapat mempengaruhi hasil penelitian ini.

\section{KESIMPULAN}

Ekspresi IL-21 pada pasien berisiko sindrom metabolik yang mendapatkan MBJH dosis $3 \mathrm{ml} /$ hari lebih tinggi dibandingkan yang mendapat dosis 1,5 ml/hari selama 21 hari.

\section{DAFTAR PUSTAKA}

Akrom, 2013, Efek pemberian MBJH selama 21 hari terhadap gambaran fungsi hepar, ginjal dan gambaran darah tepi tikus SD, Laporan Penelitian Mandiri, LPP UAD, Yogyakarta

Akrom, 2013, Mekanisme kemoprefentif ekstrak heksan BJH pada tikus SD diinduksi DMBA: kajian antioksidan dan imunomodulator, Disertasi, Program Doktor Ilmu Kedokteran dan Kesehatan FK UGM, Yogyakarta

Akrom, Mustofa, Mubarika, S., Setyanto, HNE., 2013, The chemopreventive and immunomodulator effect of black seed oil on SD rat induced by DMBA, Proceeding enhacing International collaborative research on education, sciencees and humanities, Naga City, Philipines, June 19-21, 2013 
Akrom, Nurani, L.N., Hidayati, T., 2008, Kajian aktivitas imunomodulator agen kemopreventif isolate aktif ekstrak N.sativa pada kanker payudara akibat paparan DMBA pada tikus putih, Laporan Penelitian, LPP UAD, Yogyakarta

Alberti, P. Zimmet, J. Shaw, 2006, Metabolic syndrome, a new world-wide definition. A Consensus Statement from the International Diabetes Federation, Diabetic medicine, UK

Bajak, E.Z., 2005, Genotoxic stress: novel biomarkers and detection methods uncovering RNAs role in epigenetics of carcinogenesis, Dissertation, Karolinska University Press, Sweden

Departemen Kesehatan RI, Direktorat Jenderal Pengawasan Obat dan Makanan,

El Sayed, I., \& Fukushima S., 2003, Chemopreventive potential of volatile oil from black cumin (Nigella sativa L) seeds against rat colon carcinogenesis, J Nutr Cancer, 45 (2):195-202

Farah, K.M., Atoji, Y., Shimizu, Y., Shiina, T., Nikami, H., Takewaki, T., 2004, Mechanisms of the hypoglycaemic and immunopotentiating effects of Nigella sativa L., oil in streptozotocin-induced diabetic hamsters, Res Vet Sci, 77(2):123-9

Gilani A.H., Jabeen @., Khan MAU., 200K Review of medical uses and pharmacological activities of Nigella sativa L seeds, pak J biol Sci, volume 4 halaman 441-451.

Iddalmadeniya, S.S., Thabrew, M.L., Wickramasinghe, S.M.D.N., Ratnatunge, N., Thammitiyagodage, M.G., 2006, A long-term investigation of the antihepatocarcinogenic potential of an indigenous medicine comprised of Nigella sativa, Hemidesmus indicus and Smilax gabra, J. Carcinog, 8(1):6

Islam, Muhammad T., 2016, Biological avtivities and therapeutic promises of Nigella sativa $\mathrm{L}$, international journal of Pharma sciences and scientific reserch, Volume 2 Issue 6 242-243, Departement of pharmacy Southern University Bangladesh, Bangladesh.

Kemenkes RI., Riset Kesehatan Dasar (Riskesdas) 2007, Kementrian Kesehatan, Jakarta Kemenkes RI., Riset Kesehatan Dasar (Riskesdas) 2010, Kementrian Kesehatan, Jakarta Kemenkes RI., Riset Kesehatan Dasar (Riskesdas) 2013, Kementrian Kesehatan, Jakarta

Mousa, D., Dilsiz, N., Gumushan, H., 2004, Antitumor activity of an ethanol extract of Nigella sativa seeds, Biologia-Bratislava, 59(6):735-40

Mustofa, Edi, 2012, Efek Stres Fisik dan Psikologis pada Kortisol, PGE , BAFF, IL-21, SIgA, dan Candidiasis 2 Vulvovaginal, Jurnal Kedokteran Brawijaya, Vol. 27, 24-25

Nickavar, B., Mojab, F., Javidnia, K., Amoli, M., A., 2003, Chemical composition of the fixed and volatile oils of Nigella sativa L. from Iran, J. Naturforsch, 58(9-10): 62931

Randhawa, M.A., \& Al-Ghamdi, M.S., 2002, A review of the pharmaco-therapeutic effects of Nigella sativa, Pakistan J. Med. Res., 41: 2

Ribas, A., 2007, Tremelimumab (CP-675,206), a cytotoxic T Lymphocyte Associated Antigen 4 Blocking Monoclonal Antibody in Clinical Development for Patients with Cancer, Oncology. 12 (7): 873-883

Ricky, T.N., 2011, Pengaruh pemberian terapi tambahan adjuvant minyak jinten hitam (Nigella sativa) terhadap hitung Limfosit mencit Balb/C model sepsis, Skripsi, Fakultas kedokteran Universitas Sebelas Maret: Surakarta.

Van der veen, R.C., 2001, Nitric oxide and T helper cell immunity, Int immunopharmacol, $1: 1491-500$

Vecchio, M.D., Bajetta, E., Canova, S., Lotze, M.T., Wesa, A., 2007, Interleukin-12: Biological properties and clinical application, Clin Cancer Res. 13(16):4677-4685

Wald, O., Weiss, I.D., Waldh, H., Shoham, H., Bar-shavit, Y., Beider, K., Galun,

E., Weiss, L., Flaishon, L., 2006, IFN- $\gamma$ act on T cells to induce NK cell mobilization and accmulation in target organ, J Imunol. 176:4716-29 
